\title{
Marital Assimilation and Family Financial Resources of U.S. Born Hispanics
}

\author{
Xuanning $\mathrm{Fu}^{*}$
}

Department of Sociology, California State University, Fresno, CA 93740-8019, USA

\begin{abstract}
Census 2000 5\% PUMS data are used to study the association between intermarriage and family financial resources for U.S. born Mexicans $(n=95,509)$, Puerto Ricans $(n=51,030)$ and Cubans $(n=5,688)$, based on classic and segmented assimilation theories. Findings give support to classic assimilation theory. For all three Hispanic groups exogamy with Whites leads to higher family financial resources than endogamy. Outmarriage to non-Whites is also linked to higher SES for Mexicans and Puerto Ricans, but not for Cubans. Intermarriage is also related to higher family SES for Hispanic women than for Hispanic men. Besides a symbol of assimilation, intermarriage tends to filter out low-SES Hispanics and keep them in endogamy, and is thus associated with different family financial environments for nextgeneration Hispanics.
\end{abstract}

\section{INTERMARRIAGE, ASSIMILATION AND FAMILY FINANCIAL RESOURCES: U.S. BORN HISPANICS IN 2000}

Hispanics have been the largest minority group in the United States since early 2004 [1], and one of every seven people in the nation is now Hispanic, a record number that will keep rising because of immigration and a birth rate that exceeds that of non-Hispanic Americans [2]. In the last few years Hispanic population grew three times faster than the general population, accounting for one-half of the overall population growth [3]. It is estimated that by 2050 the Hispanic population will increase from the current $13 \%$ to about $24 \%$ of the total U.S. population [4]. Hispanics in general have a low average socioeconomic status, but they differ widely across different nationality groups: Mexicans have the lowest SES while Cubans have the highest [2].

The large size, fast growth and relatively low SES of the Hispanics raise important research questions about how Hispanics assimilate into the American society. Intermarriage is presumably an indicator of such assimilation, especially when the marriage is with Whites. Evidence from 1970 to 1990 census data suggested that despite experiences of discrimination and overall low SES, Hispanics (Mexicans in particular) seemed to be fast assimilating into the mainstream America through intermarriage with Whites [2].

Prior studies of Hispanic assimilation and intermarriage mostly used marriage formation as an indicator of assimilation, and little attention has been paid to how intermarriage might be associated with family financial well-being of the future generation Hispanics. In this study, I use 2000 census 5\% PUMS data to test classic and segmented assimilation theories [5], and to examine how marriage types are related to family financial resources.

*Address correspondence to this author at the Department of Sociology, California State University, Fresno, CA 93740-8019, USA; E-mail: xfu@csufresno.edu

\section{HISPANIC INTERMARRIAGE AND ASSIMILATION}

Intermarriage has been steadily increasing in the last few decades in the United States, with its percent out of all marriages growing from $0.7 \%$ in 1970 to $5.4 \%$ in 2000 , and its actual number rising by ten folds in the same period [6]. The number of Americans who claim multiple racial and ethnic backgrounds also increased as a result of rising intermarriages, estimated to reach $21 \%$ of the total population by 2050 [7].

Inter-Hispanic marriages (marriages between Hispanics and non-Hispanics) rose rapidly in the same period, from 600,000 to 1.8 million [8]. This increase mostly reflected the fast population growth of the Hispanics due to large influxes of new immigrants, because the Hispanic intermarriage rate has remained rather stable at about $25 \%$. This rate, however, is relatively high when group sizes are taken into account, especially when compared to Blacks who have a comparable group size with Hispanics [9]. To be specific, Hispanics are much more likely to outmarry than Blacks, but are less so than smaller minority groups such as Asians, Native Americans or Hawaiians. Because outmarriage rate is largely determined by group size, smaller Hispanic groups, such as Cubans, usually have higher exogamy rates than larger groups, such as Mexicans [10].

In terms of individual characteristics, outmarrying Hispanics are similar to other exogamous Americans: they tend to be native-born (second and subsequent generations are more likely to outmarry), belong to younger cohorts and have higher SES. Based on these traits, intermarriage is often taken as a sign of successful assimilation for minorities [11], but there have appeared two schools of thoughts on how the late 20th century immigrants will assimilate as compared to immigrants from Europe a century ago.

The first school of thoughts was developed in the early and mid $20^{\text {th }}$ century. Because all immigrants experience at least some form of integration into their host society, sociologists observed in the early $20^{\text {th }}$ century that intermarriage was often the ultimate form of assimilation, especially 
when the marriage was between ethnic immigrant minorities and members of the dominant group (White-Anglo American) [12]. Based on these earlier theoretical assumptions from Hansen and Merton, Gordon in 1964 posited a straightline 3-step assimilation model for European immigrants. Immigrants are hypothesized to first acculturate into America, then structurally merge into the mainstream U.S. society, and finally marry other Americans to eventually complete their assimilation process [13]. Cultural and structural assimilations can be represented by obtaining formal education and securing middle class jobs and income, and these steps are to be completed before marital assimilation occurs. Gordon's model of assimilation was in general supported by historical data on European immigrants of various backgrounds, and his work is often referred to as the classic model of assimilation [14].

The second school of thoughts was built on critiques of Gordon's model of assimilation, and on the emergence of a pluralistic American society in the late $20^{\text {th }}$ century. It is often referred to as a model of "segmented assimilation", which argues that Gordon's theory of assimilation was mainly developed to describe immigrants from Europe in the late 19th and the early 20th century, but is insufficient in describing recent immigrants who came primarily from Latin America, Asia and the Pacific, with very different racial, ethnic and religious characteristics from the earlier European immigrants. In other words, the recent immigrants are socially more distant from the Anglo Americans than the earlier European immigrants, and their assimilation into America would be more difficulty, if at all possible [15]. In fact, the new immigrants would experience a "segmented assimilation". Some of them may integrate into the middleclass society just as Gordon projected, others might be permanently mired in the impoverished, alienated and marginalized segments of racial minority groups, and still others may form close-knit enclaves based on their traditional cultures and resist the forces of assimilation. Those who 'assimilate' into the marginalized segments of the U.S. society would probably identify themselves with inner city underclass America rather than with the mainstream middle class America [16]. The primary reasons for segmented assimilation are racial discrimination, self-maintained ethnic solidarity and enclaves, and the nature of the secondary labor market those immigrants find themselves in [17]. The economically deprived immigrant minorities may also intermarry other poor minorities to form a unique subculture (of poverty). To them, Americanization actually means a membership into the inner-city underclass [18].

Supporters of Gordon's classic assimilation theory contend that the straight-line assimilation path is still applicable to the late 20th and early 21 st century immigrants [19]. Alba and Nee found that most contemporary immigrant groups are acculturating and integrating at the 'normal' 3-geneation pace as Gordon hypothesized in the 1960s about European immigrants. That is, by the third generation in America, the new immigrant groups are no different from the previous century European immigrants in degrees of assimilation, including their intermarriage rates [20].

Rosenfeld tested the segmented assimilation theory using 1970 to 1990 census data on Mexican Americans [2]. Since a large proportion of Mexican Americans have menial jobs, low income and tend to live in their enclaves, Rosenfeld argued that if the segmented assimilation theory were correct about intermarriage, data would reveal that Mexicans have a tendency to marry poor Blacks and other poor minorities, as evidence of segmented assimilation into underclass America. He found, however, segmented assimilation assumptions were not supported by the 1970 to 1990 census data, and Mexican Americans had no apparent social barriers from integrating into White America. Mexican intermarriage with Blacks or other minorities was very rare, if at all.

\section{STATUS EXCHANGE IN INTERMARRIAGE}

A fundamental assumption about intermarriage is that such marriages are based on equal status exchange between husband and wife. Recent literature on assortative marriages by education and on critique of the exchange theory has provided strong support to this perspective [21]. Previously, intermarriage between Whites and non-Whites was considered an exchange of unequal status, with the minority spouse trading higher achieved status for racial caste status of the White spouse [22]. Census data from the last 30 years suggested that this unequal status exchange was weak and unreliable, if it ever existed [23]. The increased educational levels of Americans in the last few decades perhaps have strengthened the patterns of equal status exchange in mate selection, either the union is endogamous or exogamous [24].

Equal status exchange between husbands and wives of different racial or ethnic groups, however, may lead to marriages of individuals who came from different strata of their originating groups. Relatively high-status individuals from low-status groups will likely marry low-status individuals from high-status groups when they match their statuses [25]. Presumably, high-status Hispanics are more likely to outmarry Whites than would low-status Hispanics. Intermarriage thus may serve as a filter to keep low-SES Hispanics in endogamy and to preserve social classes by race and Hispanic identity across generations.

\section{INTERMARRIAGE, ASSIMILATION AND FAMILY FINANCIAL STATUS}

In this study, I test the classic assimilation and segmented assimilation theories from a different angle: how is intermarriage (a symbol of assimilation) associated with family financial resources for Hispanics, and how might this relationship affect the next generation?

The number of children living in intermarried Hispanic families increased from 800,000 in 1970 to over 2 million in 2000 , and about two-third of these children in 2000 selfidentified as Hispanic $[2,4]$. This self-identification undoubtedly helped the increase of the U.S. Hispanic population, but it also indicated that Hispanic children's family SES might be increasingly related to their parents' type of marriage, which in turn might affect the children's assimilation and intermarriage.

The classic assimilation theory assumes that outmarriage to Whites is a symbol of successful assimilation into the middle class, and Hispanics who outmarried Whites would have achieved cultural and structural assimilations, and would be educationally, occupationally and financially better 
off than their endogamous counterparts. In other words, exogamous Hispanics should have higher individual SES than their endogamous counterparts. Because marriage tends to couple individuals with similar SES, family financial resources would be polarized between exogamous Hispanics (to Whites) and endogamous Hispanics. The theory, however, says little about other types of intermarriages (to non-Whites).

The segmented assimilation theory acknowledges that outmarriage to Whites is a symbol of final assimilation into middle-class America, but does not see Hispanic endogamy as necessarily associated with lower family SES because structurally assimilated Hispanics (those with high individual SES) may not choose to marry Whites. In addition, the theory predicts Hispanic intermarriages to non-Whites, primarily between low-SES individuals as a symbol of assimilation into underclass America [2,16]. A variety of assimilation pathways are thus hypothesized by the theory: highachieving Hispanics may outmarry Whites or marry endogamously, and both of these Hispanic families may have relatively high family SES; Hispanics who are not structurally assimilated tend to marry endogamously or outmarry nonWhites, and their families would have low SES.

\section{HISPANIC NATION-ORIGIN GROUPS AND NATIVITY}

The above assumptions about intermarriage, assimilation and family financial well-being will be tested separately on Mexicans, Puerto Ricans, and Cubans, the three largest Hispanic nationalities in the U.S. These three groups account for over three-quarters of all Hispanics, but they differ greatly in socioeconomic status and in scales of immigration and intermarriage [4].

From 1970 to 2000, both Cubans and Puerto Ricans had faster outmarriage rate increases than Mexicans, but that difference mainly reflected the different scales of immigration among the three groups rather than a varying pace of assimilation. Mexicans are the largest immigrant group and many of the Mexican newcomers were already married upon arrival, almost exclusively in endogamous unions. These factors may have contributed to Mexicans' overall slower growth in outmarriage rates. In addition, new Mexican immigrants have the lowest average SES among all immigrant groups, which makes them less likely to outmarry even if they were single upon arrival, further lowering the overall intermarriage rate among Mexicans $[2,15]$.

A unique consideration in studying immigrant intermarriages is how to separate immigrants married abroad (IMAs) from those who married after immigration and those who were U.S. born [26]. Data from Immigration and Naturalization Services suggested that in the last thirty years about half of the immigrants were married at the time of admission, but this rate varied dramatically across groups [27]. Large scales of immigration often quickly change the demographic profiles of a minority group, including its outmarriage rates. If IMAs are not identified, intermarriage studies may generate misleading results about assimilation for immigrant minorities. For example, Lee and Fernandez analyzed the 1980 and 1990 census data, and reported that Asian intermarriage rates declined over the decade due to immigration. Although they pointed at immigration as the cause of the decline, they didn't quantify how the addition of new IMAs affected the overall Asian intermarriage rates, leaving the impression that Asians had become less assimilated from the 1980 s to 1990 s by resisting intermarriages [28].

Hwang and Saenz (1990) and Alba and Golden (1986) discussed how to separate IMAs from non-IMAs in the census data, such as checking place and year of marriage with timing of immigration. Those remedies are often inaccurate, and may lead to unknown proportions of errors [26,29]. They are not applicable to the 2000 census, either, because the latest census ceased to provide information on year of marriage and timing of immigration. To accurately assess the relationship between Hispanic intermarriage, assimilation and family financial well-being, it is important that IMAs are accounted for. In this study, only U.S. born Hispanics will be included in the analysis.

The selection of U.S. born Hispanics offers at least two advantages. First, outmarriage can be compared between groups without the uncertainty that unknown proportions of IMAs are embedded in the data. U.S. born Hispanics are about three times more likely to intermarry than their foreign-born counterparts as revealed by census data, but this strong positive effect of nativity on outmarriage may be overstated because of the failure to identify IMAs. Studying U.S. born Hispanics can avoid this problem. Second, acculturation and structural incorporations of the U.S. born Hispanics can be anticipated in the same theoretical framework as for all native-born Americans, especially concerning the effect of SES. For example, the effect of college education on outmarriage may be greater for native-born U.S. citizens than for foreign born immigrants who obtained college education abroad but married after immigration, because U.S. educational institutions provide greater interracial contacts $[2,21]$.

\section{HYPOTHESES}

Based on predictions of classic and segmented assimilation theories about intermarriage, this study tests four hypotheses on the association between marriage type and financial well-being of U.S. born Hispanic families. It is important to note that although no causal link can be assumed by using the census data, family financial resources are measured after marriage, pooling earnings of the two spouses who tend to have similar SES. Marriage type is thus associated with different family financial resources based on the SES of the individual spouses.

1. Hispanics intermarried to non-Hispanic Whites are culturally and structurally assimilated. They have higher individual SES and higher family financial resources in their married households than Hispanics who are endogamously married.

2. Hispanics intermarried to non-Whites are not culturally or structurally assimilated. They have lower individual SES and lower family financial resources in their married households than Hispanics who are outmarried to Whites.

3. Endogamous Hispanics are either structurally assimilated and choose not to outmarry, or are not structurally assimilated and consequentially unlikely to 
outmarry. Their individual SES and family financial resources would be either relatively high or very low, with the overall average resting between Hispanics who are outmarried to Whites and Hispanics who are outmarried to non-Whites.

4. The above three hypotheses would apply equally to Hispanic men and Hispanic women, and there is no financial difference by gender in Hispanic intermarriages.

Hypothesis 1 tests the classic assimilation theory, which is also one of the outcomes assumed by segmented assimilation theory. Hypotheses 2 and 3 are unique to the predictions of the segmented assimilation theory. Hypothesis 2 will be tested by comparing three types of intermarriages: Hispanic-Whites, Hispanic-Blacks, and Hispanic-Others. Blacks are a separate non-White group because they are the second largest minority in the nation and can provide enough sampled families in the data. They also offer a re-test of Rosenfeld's work on Mexican assimilation via intermarriage, in which Mexican-Black marriages were conceptualized as evidence of segmentation into underclass America. The Hispanic-Other group combines all non-Black minorities because their small sizes do not allow them to remain as separate test categories.

Hypothesis 3 indicates that both relatively high-SES and low-SES Hispanics may marry endogamously, so that endogamous Hispanic families have a wider dispersion in their financial resources than expected of intermarried Hispanic families, with their average somewhere between families of Hispanic-Whites and families of Hispanic-nonWhites.

Hypothesis 4 is based on the equal status exchange assumption, anticipating no gender difference in the association between intermarriage and family financial resources. The previous three hypotheses would apply in the same way for both Hispanic men and women. If intermarried Hispanic husband families have higher family SES than endogamous Hispanic families, the same is anticipated for intermarried Hispanic wife families. In addition, exogamous Hispanic families would have similar SES either the Hispanic spouse is a man or is a woman. Literature on intermarriage has noted a gender difference in outmarriage rates [11,30], especially among Asians and Blacks. Hypothesis 4, however, assumes similar family financial consequences for Hispanic men and Hispanic women, not their intermarriage rates.

These hypotheses will be tested by including a number of control variables, such as age, education, job prestige, and employment status of the couples. Age is important because earning power often increases with age. Education and job prestige are both correlated with income, and they are also indicators of cultural and structural assimilation. Employment status indicates if one, both or neither spouse work for pay, and is hypothesized to correlate with total family income.

\section{METHOD}

\section{Data and Variables}

Analysis in this study is based on existing marriages in the $20005 \%$ PUMS national data, limited to U.S. born
Hispanics (about 53\% of all married Hispanic couples are U.S. born). Compared to newlyweds, existing marriages might be subject to biases due to selective marital dissolution, changed SES after marriage, and remarriage [31]. But these factors are important in determining the overall social distance between the originating racial/ethic groups of the intermarried couples. In other words, the 'surviving' intermarriages better illustrate how intermarriage is related to family financial status. Existing marriages also represent all married households at a given time, so as to provide an understanding how status matching in marriages reflects assimilation and affects family resources for children. Using census data to study immigrant intermarriages has been commonly reported in the literature $[2,6,21]$.

There are a total of 23 Hispanic nation-origin groups in the 2000 census PUMS, but Mexicans, Puerto Ricans and Cubans compose $76.6 \%$ of all Hispanic husbands and $74.4 \%$ of all Hispanic wives. These three groups will be analyzed separately, and the remaining 20 groups are combined and included in 'outgroup Hispanics'. For example, a Mexican and 'outgroup Hispanic' marriage would have one Mexican spouse and one Hispanic spouse who is not Mexican (from any of the 22 groups).

Marriage type is the primary independent variable, and it is measured by race and Hispanic nation-origin of both spouses, resulting in nine different categories: endogamy, exogamy to an outgroup Hispanic husband or wife, exogamy to a White husband or wife, exogamy to a Black husband or wife, and exogamy to an 'Other' husband or wife (nonWhite and non-Black).

The dependent variable in the study, family financial resources, is measured in three aspects: per capita income, percents of living in poverty and percents of having an income 5 times above poverty. These three measures give a more comprehensive coverage of family financial resources than income alone, which is often subject to regional variations and to skewed distributions. Percents of poverty represent the lower end of family resources, and percents of having an income 5 times above poverty, an income to poverty ratio in the census data [15], reflect the higher end of family resources. Both can be compared nationally across regions.

A number of control variables will be used in the analysis, including education, job prestige, age and employment status of the married couples. Household sizes are also controlled when family financial resources are measured as per capita income and percents of poverty.

Education in the 2000 census PUMS data is a 16-point scale that records levels of education from no schooling to Doctorate degree, with a mean of 10.24 and 10.25 respectively for all U.S. born husbands and wives. Occupation is a categorical variable with hundreds of detailed job titles. To better capture the degrees of structural assimilation, occupation is recoded into a job prestige variable by assigning scores from the adjusted Standard International Occupational Prestige Scale (SIOPS). The adjusted SIOPS was developed on the basis of Treiman's original SIOPS (in 1977) by incorporating the updated international standard classification of occupations [32]. The adjusted SIOPS has been 
empirically tested and was believed to have a high level of validity [33].

\section{Statistical Analysis}

Education, job prestige and annual income of the married Hispanics and their spouses are presented in Table $\mathbf{1}$ to $\mathbf{3}$, respectively for Mexicans, Puerto Ricans and Cubans. These individual SES measures illustrate differences in cultural and structural assimilations by marriage type. Outmarriage rates by spouses' race or ethnicity are also given in these tables. Total family income, percents in poverty and percents of having an income 5 times above poverty are shown in Table 4.

Three multivariate analyses follow the descriptive tables. A linear regression model compares per capita income across different types of Hispanic families (Table 5), and it is followed by two logistic regression analyses that predict odds of living in poverty and odds of having an income 5 times above poverty (Table 6). All three regression analyses control for education, occupational prestige, age, and employment status of the married couples.

\section{FINDINGS}

Table 1 lists individual SES indicators for Mexican couples by nine types of marriages. The 'Non-Mexican Hispanics' in Row 2 are Hispanic wives who are not Mexican, and in Row 3 they are Hispanic husbands who are not Mexican. In Row 8 and 9 the 'other non-Hispanic' spouses are neither White nor Black. All Mexican marriages and national averages are also shown in the table.

About two thirds of the U.S. born Mexican Americans are endogamously married, and roughly a quarter are married to non-Hispanic Whites. Less than $9 \%$ are married to outgroup Hispanics, Blacks and others. Difference in these outmarriage rates is very small between genders.

Socioeconomically, endogamous Mexicans trail exogamous Mexicans in all three individual SES measures (education, job prestige and income), with the only exception that endogamous Mexican husbands have higher average income than Mexican husbands who are married to Blacks. Husbands and wives in all types of marriages have closely matched education and job prestige, but they differ in income with an advantage for husbands. This advantage, however, is rather consistent across the different marriage types. Husbands and wives in Mexican-White marriages have the highest SES among all husbands and wives, and the difference is especially large in income.

Table 2 shows SES comparisons for Puerto Ricans. Puerto Ricans have a lower intermarriage rate than Mexicans, with only $9 \%$ outmarried to Whites, less than $5 \%$ outmarried to outgroup Hispanics, and 1 to $2 \%$ outmarried to Blacks and Others. These rates are largely the same between genders. Similar to Mexicans, endogamous Puerto Rican couples fall behind their exogamous counterparts in all three SES measures, but the difference is much larger for Puerto

Table 1. Mexicans: Average Education, Job Prestige and Individual Annual Income by Type of Marriages $(n=95,509)$

\begin{tabular}{|c|c|c|c|c|c|c|c|c|c|c|}
\hline & \multirow{2}{*}{ Marriage Type } & \multicolumn{2}{|c|}{ Education $^{1}$} & \multicolumn{2}{|c|}{$\mathbf{J o b}^{1}$} & \multicolumn{2}{|c|}{ Income $^{1}$} & \multirow{2}{*}{$\begin{array}{c}\text { \# of } \\
\text { Couples }\end{array}$} & \multicolumn{2}{|c|}{$\%$ of all Mexicans } \\
\hline & & Husband & Wife & Husband & Wife & Husband & Wife & & Husband & Wife \\
\hline \multirow[t]{2}{*}{1} & Endogamous Mexicans & 8.0 & 8.2 & 37.2 & 38.9 & $\$ 30,786$ & $\$ 13,681$ & 47,475 & $67.0 \%$ & $65.8 \%$ \\
\hline & Outmarried to Non-Mexican Hispanics & & & & & & & & & \\
\hline 2 & Mexican husband & 8.0 & 8.6 & 37.1 & 39.0 & $\$ 31,603$ & $\$ 14,888$ & 3,817 & $5.4 \%$ & \\
\hline 3 & Outmarried to non-Hispanic Whites & & & & & & & & & \\
\hline 4 & Mexican husband & 9.8 & 10.3 & 40.5 & 41.6 & $\$ 41,628$ & $\$ 21,174$ & 17,201 & $24.3 \%$ & \\
\hline \multirow[t]{2}{*}{5} & Mexican wife & 10.8 & 10.2 & 43.5 & 41.6 & $\$ 50,790$ & $\$ 20,131$ & 18,853 & & $26.1 \%$ \\
\hline & Outmarried to non-Hispanic Blacks & & & & & & & & & \\
\hline 7 & Outmarried to other non-Hispanics & & & & & & & & & \\
\hline 8 & Mexican husband & 9.4 & 9.9 & 38.9 & 40.1 & $\$ 37,682$ & $\$ 19,624$ & 1,940 & $2.7 \%$ & \\
\hline \multirow[t]{3}{*}{9} & Mexican wife & 10.2 & 9.7 & 41.1 & 40.4 & $\$ 42,705$ & $\$ 18,329$ & 1,624 & & $2.3 \%$ \\
\hline & All Mexican marriages ${ }^{2}$ & 9.0 & 9.1 & 39.3 & 40.1 & $\$ 37,210$ & $\$ 16,706$ & 95,509 & $100.0 \%$ & $100.0 \%$ \\
\hline & All marriages (national average) & 10.2 & 10.3 & 43.0 & 42.3 & $\$ 49,111$ & $\$ 19,960$ & $2,569,580$ & & \\
\hline
\end{tabular}

Note:

1. Education ranges from no schooling to Doctorate on a scale of 1 to 16. Job prestige scores are based on Garzeboom and Treiman's Standard International Occupational Prestige Scale (1996). Income is U.S. dollars in 1999.

2. All Mexican marriages include all couples of whom at least one spouse is Mexican. 
Table 2. Puerto Ricans: Average Education, Job Prestige and Individual Annual Income by Type of Marriages $(\mathrm{n}=51,030)$

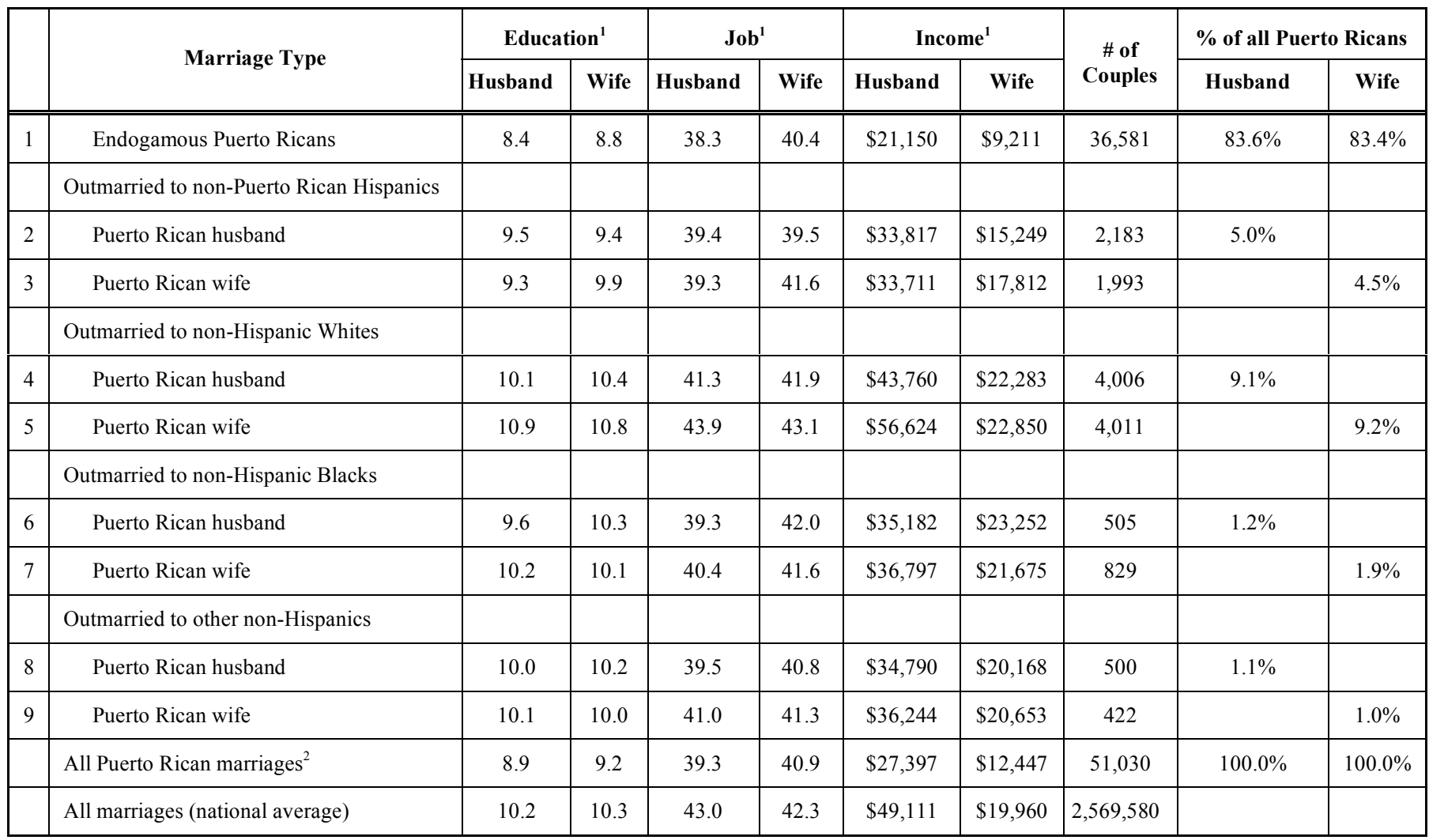

Note:

1. See Note 1 in Table 2.

2. All Puerto Rican marriages include all couples of whom at least one spouse is Puerto Rican.

Ricans than for Mexicans. Puerto Rican husbands who married White wives have an annual income twice as high as that of endogamous Puerto Rican husbands $(\$ 43,760$ vs. $\$ 21,150)$, and the comparable ratio is 2.5 times for Puerto Rican wives (\$22,850 vs. \$9,211).
Cubans clearly have a different pattern from Mexicans and Puerto Ricans, as shown in Table 3. Cubans are the most exogamous among the three groups, with only slightly above a quarter endogamously married. Most of the exogamous Cubans, about half of all Cuban husbands and wives, are married to Whites. Over $20 \%$ of Cuban husbands and $14 \%$

Table 3. Cubans: Average Education, Job Prestige and Individual Annual Income by Type of Marriages $(\mathrm{n}=5,688)$

\begin{tabular}{|c|c|c|c|c|c|c|c|c|c|c|}
\hline & \multirow{2}{*}{ Marriage Type } & \multicolumn{2}{|c|}{ Education $^{1}$} & \multicolumn{2}{|c|}{$\mathbf{J o b}^{1}$} & \multicolumn{2}{|c|}{ Income $^{1}$} & \multirow{2}{*}{$\begin{array}{c}\text { \# of } \\
\text { Couples }\end{array}$} & \multicolumn{2}{|c|}{$\%$ of all Cubans } \\
\hline & & Husband & Wife & Husband & Wife & Husband & Wife & & Husband & Wife \\
\hline 1 & Endogamous Cubans & 10.5 & 10.9 & 44.3 & 45.1 & $\$ 53,722$ & $\$ 26,778$ & 878 & $26.0 \%$ & $27.5 \%$ \\
\hline & Outmarried to non-Cuban Hispanics & & & & & & & & & \\
\hline 2 & Cuban husband & 10.2 & 10.4 & 42.9 & 42.8 & $\$ 45,857$ & $\$ 21,087$ & 699 & $20.7 \%$ & \\
\hline 3 & Cuban wife & 10.7 & 10.9 & 44.5 & 44.9 & $\$ 45,747$ & $\$ 23,629$ & 456 & & $14.3 \%$ \\
\hline & Outmarried to non-Hispanic Whites & & & & & & & & & \\
\hline 4 & Cuban husband & 11.5 & 11.3 & 48.1 & 45.3 & $\$ 70,394$ & $\$ 28,818$ & 1,654 & $49.1 \%$ & \\
\hline 5 & Cuban wife & 11.8 & 11.5 & 47.6 & 46.8 & $\$ 73,067$ & $\$ 29,934$ & 1,718 & & $53.8 \%$ \\
\hline & Outmarried to non-Hispanic Blacks & & & & & & & & & \\
\hline 6 & Cuban husband & 10.0 & 10.5 & 40.8 & 42.7 & $\$ 35,179$ & $\$ 23,470$ & 61 & $1.8 \%$ & \\
\hline 7 & Cuban wife & 10.9 & 11.3 & 42.9 & 45.0 & $\$ 45,966$ & $\$ 25,745$ & 77 & & $2.4 \%$ \\
\hline & Outmarried to other non-Hispanics & & & & & & & & & \\
\hline
\end{tabular}


(Table 3) Contd.....

\begin{tabular}{|c|c|c|c|c|c|c|c|c|c|c|}
\hline & Marriage Type & \multicolumn{2}{|c|}{ Education $^{1}$} & \multicolumn{2}{|c|}{$\mathbf{J o b}^{1}$} & \multicolumn{2}{|c|}{ Income $^{1}$} & $\begin{array}{c}\text { \# of } \\
\text { Couples }\end{array}$ & \multicolumn{2}{|c|}{$\%$ of all Cubans } \\
\hline 8 & Cuban husband & 10.9 & 11.1 & 44.7 & 45.1 & $\$ 43,817$ & $\$ 25,651$ & 79 & $2.3 \%$ & \\
\hline 9 & Cuban wife & 11.2 & 11.2 & 42.7 & 43.0 & $\$ 56,580$ & $\$ 26,625$ & 66 & & $2.1 \%$ \\
\hline & All Cuban marriages ${ }^{2}$ & 11.2 & 11.2 & 46.2 & 45.3 & $\$ 62,399$ & $\$ 27,306$ & 5,688 & $100.0 \%$ & $100.0 \%$ \\
\hline
\end{tabular}

Note:

1. See Note 1 in Table 2.

2. All Cuban marriages include all couples of whom at least one spouse is Cuban.

Cuban wives are married to outgroup Hispanics, and just $1 \%$ to $2 \%$ Cubans are married to Blacks and others. The endogamous Cubans have lower SES than Cubans who are outmarried to Whites, higher SES than Cubans who are outmarried to non-Cuban Hispanics and Blacks, but are comparable to Cubans who are outmarried to non-Hispanic others (neither White nor Black).

Table 1 to $\mathbf{3}$ revealed four trends. First, Hispanics who are married to Whites in all three nation-origin groups have higher individual SES than those who are in other types of marriages. Second, endogamous Mexicans and Puerto Ricans tend to have lower SES than their outmarried counterparts, regardless to whom they are outmarried; but endogamous Cubans have higher SES than Cubans who are outmarried to non-Whites. Third, the SES difference summarized in the first two trends is relatively small in education and job prestige, but large in income. Lastly, there is little gender difference in intermarriage rates, but husbands of exogamous Hispanic wives have higher income than exogamous Hispanic husbands after controlling for race/ethnicity of their spouses (Income in Row 3, 5, 7, and 9 are respectively higher than in Row 2, 4, 6, and 8).

Total family income, percents of living in poverty and percents of having an income 5 times above poverty are presented in Table $\mathbf{4}$ for the three Hispanic groups by nine marriage types. The outgroup Hispanics in Column 2 and 3 refer to any Hispanics who are not from the nation-origin group on the row, so that they are non-Mexican Hispanics in Mexican marriages, non-Puerto Rican Hispanics in Puerto Rican marriages and non-Cuban Hispanics in Cuban marriages. Take Mexicans for example, Column 1, 2 and 3 are respectively endogamous Mexican families, Mexican

Table 4. Hispanic Total Family Income, \% in Poverty, \% with Income 5 Times Above Poverty and Household Size by Type of Marriage

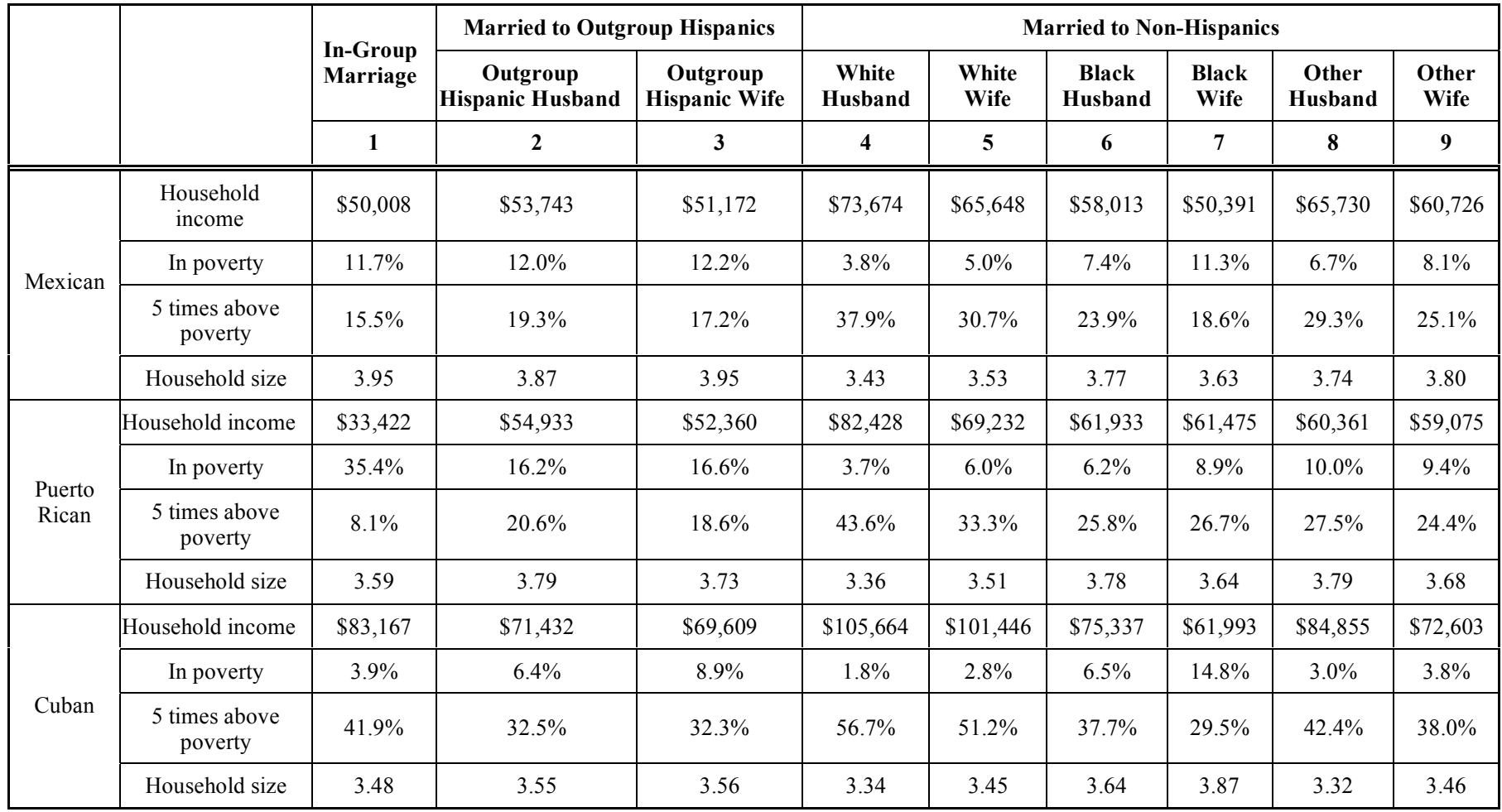

Note: Outgroup Hispanic spouses (Column 2 and 3) are Hispanics who are not from the nation-origin group defined on the row. They are non-Mexican Hispanics in Mexican marriages, non-Puerto Rican Hispanics in Puerto Rican marriages and non-Cuban Hispanics in Cuban marriages. 
wife and non-Mexican Hispanic husband families, and Mexican husband and non-Mexican Hispanic wife families. Column 4 and 5 are Mexican wife with White husband families and Mexican husband with White wife families. Similarly, Mexican wife with Black husband families and Mexican husband with Black wife families are in Column 6 and 7, and Mexican wife with other non-Hispanic husband families and Mexican husband with other non-Hispanic wife families are in Column 8 and 9.

Endogamous Mexican and Puerto Rican families tend to have lower total family income, higher poverty rates and lower rates of 5-times-above-poverty income, than their outmarried counterparts, especially those with a White spouse. Compared to Mexican-White families, endogamous Mexican families have a total income that is $31 \%$ to $47 \%$ lower, are 2.3 to 3 times more likely to live in poverty, and 2 to 2.4 times less likely to have an income 5 times above poverty. Similar financial disadvantages are found between endogamous Mexican families and the other types of exogamous Hispanic families, albeit the differences are smaller. The only exception is that the poverty rate for endogamous Mexican families is slightly lower than for Mexicanoutgroup Hispanic families (Column 2 and 3).
Disparities in financial resources by marriage type are much greater for Puerto Ricans. Compared to Puerto RicanWhite families, endogamous Puerto Rican families have a total family income that is $107 \%$ to $146 \%$ lower, are 5.9 to 9.6 times more likely to be poor, and 4.1 to 5.4 times less likely to have a five-times-above-poverty income. These differences are smaller but nevertheless substantial between endogamous Puerto Rican families and other types of intermarried Puerto Rican families.

Cubans have a different pattern from Mexicans and Puerto Ricans. Although endogamous Cuban families have lower financial resources by all three measures than exogamous Cuban families that have a White spouse, they are better off than Cuban-outgroup Hispanic families (Column 2 and 3) and Cuban-Black families (Column 6 and 7), and are comparable to Cuban-Other families (Column 8 and 9).

What is hinted in Table $\mathbf{1}$ to $\mathbf{3}$ but apparent in Table $\mathbf{4}$ is the gender difference. Family financial resources are higher in families with exogamous Hispanic wives than in families with exogamous Hispanic husbands. For example, income in White husband and Hispanic wife families (Column 2) is higher than in White wife and Hispanic husband families (Column 3). In fact, all three financial indicators are better in

Table 5. Regression Coefficients Showing Associations between Marriage Type and Per Capita Income

\begin{tabular}{|c|c|c|c|c|c|c|c|c|c|}
\hline \multirow{2}{*}{$\begin{array}{c}\text { Predictors } \\
\text { Marriage Type }^{1}\end{array}$} & \multicolumn{3}{|c|}{ Mexican $^{4}$} & \multicolumn{3}{|c|}{ Puerto Rican ${ }^{4}$} & \multicolumn{3}{|c|}{ Cuban $^{4}$} \\
\hline & 1 & 2 & & 3 & 4 & & 5 & 6 & \\
\hline Outgroup Hispanic husband ${ }^{2}$ & 859 & 0.008 & $*$ & 4,989 & 0.055 & $* * *$ & $-2,564$ & -0.023 & \\
\hline Outgroup Hispanic wife ${ }^{2}$ & 1,178 & 0.013 & $* * *$ & 5,565 & 0.064 & $* * *$ & $-2,025$ & -0.022 & \\
\hline White husband & 4,295 & 0.096 & $* * *$ & 11,845 & 0.187 & $* * *$ & 3,619 & 0.055 & $* *$ \\
\hline White wife & 2,642 & 0.058 & $* * *$ & 8,834 & 0.140 & $* * *$ & 3,057 & 0.046 & $*$ \\
\hline Black husband & 150 & 0.001 & & 5,752 & 0.045 & $* * *$ & & & \\
\hline Black wife & 116 & 0.000 & & 6,656 & 0.040 & $* * *$ & & & \\
\hline Other husband & 1,849 & 0.013 & $* * *$ & 7,020 & 0.038 & $* * *$ & & & \\
\hline Other wife & 1,577 & 0.013 & $* * *$ & 6,470 & 0.039 & $* * *$ & & & \\
\hline \multicolumn{10}{|l|}{ Employment status ${ }^{3}$} \\
\hline One spouse works & $-2,661$ & -0.061 & $* * *$ & $-2,959$ & -0.063 & $* * *$ & $-3,416$ & -0.045 & $* *$ \\
\hline Neither spouse works & $-2,935$ & -0.034 & $* * *$ & $-3,295$ & -0.048 & $* * *$ & $-5,533$ & -0.030 & $*$ \\
\hline Husband's job & 194 & 0.129 & $* * *$ & 225 & 0.144 & $* * *$ & 337 & 0.158 & $* * *$ \\
\hline Wife's job & 148 & 0.093 & $* * *$ & 181 & 0.109 & $* * *$ & 217 & 0.089 & $* * *$ \\
\hline Husband's education & 863 & 0.141 & $* * *$ & 845 & 0.120 & $* * *$ & 1,331 & 0.108 & $* * *$ \\
\hline Wife's education & 810 & 0.117 & $* * *$ & 447 & 0.057 & $* * *$ & 1,811 & 0.131 & $* * *$ \\
\hline Husband's age & 224 & 0.137 & $* * *$ & 136 & 0.074 & $* * *$ & 333 & 0.110 & $* * *$ \\
\hline Wife's age & 196 & 0.115 & $* * *$ & 206 & 0.105 & $* * *$ & 117 & 0.036 & \\
\hline$R^{2}$ & 0.232 & & & 0.219 & & & 0.186 & & \\
\hline
\end{tabular}

$* \mathrm{P}<0.05 . * * \mathrm{P}<0.01 . * * * \mathrm{P}<0.001$.

Note:

1. Displayed marriage types are compared against endogamous marriages for each group.

2. See Note in Table $\mathbf{4}$ for definition of 'Outgroup Hispanic husband and wife'.

3. Employment status (one or neither spouse works) is compared against 'both spouses work'.

4. Unstandardized and standardized coefficients are respectively shown in Column 1,3, 5 and 2, 4, 6. 
Column 2, 4, 6, and 8 than in Column 3, 5, 7, and 9, respectively for the three Hispanic nation-origin groups. This is mainly a reflection of the greater income difference between husband and wife in exogamous Hispanic wife families than in exogamous Hispanic husband families. Stated differently, husbands of exogamous Hispanic wives have higher individual income than exogamous Hispanic husbands, after race of the non-Hispanic spouse is controlled. Intermarriage seems to be associated with greater family financial resources for Hispanic women than for Hispanic men.

Table 5 shows linear regression coefficients (both unstandardized and standardized) that compare effects of marriage type on per capita income, controlling for the couple's education, job prestige, age, and employment status. Per capita income is used as the dependent variable because it takes into consideration household sizes. Unstandardized coefficients are shown together with the more commonly reported standardized coefficients, so that the 'dollar effect' of intermarriage can be directly compared. Each of the three Hispanic nation-origin groups has their separate regression models.
Marriage type and employment status in the model are categorical variables. The displayed marriage types are compared against endogamous marriages and the displayed employment status (one or neither spouse works) is compared against "both spouses work". In the Cuban model, outmarriages to Blacks and Others are omitted, due to small sample sizes (These four omitted groups have sample sizes ranging from 61 to 79. See Table 3).

The effects of the control variables are as expected, with higher education, higher job prestige, older age and more spouses working associated with higher per capita income.

Except Mexican-Black families, all types of exogamous Mexican families have higher per capita income than endogamous Mexican families, ranging from $\$ 859$ in outgroup Hispanic husband families to $\$ 4,295$ in White-husband families. Similarly, all exogamous Puerto Rican families have higher per capita income than endogamous Puerto Rican families, with a difference ranging from $\$ 5,000$ to almost $\$ 12,000$, much larger than found with Mexicans. On the other hand, endogamous Cuban families trail CubanWhite families by over $\$ 3,000$ in per capita income, but they

Table 6. Logistic Regression Coefficients (Odds Ratio) Showing Associations between Marriage Type and Poverty, and between Marriage Type and having an Income 5 Times above Poverty

\begin{tabular}{|c|c|c|c|c|c|c|}
\hline \multirow{2}{*}{ Predictors } & \multicolumn{2}{|c|}{ Mexican } & \multicolumn{2}{|c|}{ Puerto Rican } & \multicolumn{2}{|c|}{ Cuban } \\
\hline & 1 & 2 & 3 & 4 & 5 & 6 \\
\hline Marriage Type $^{1}$ & Poverty & Income $^{4}$ & Poverty & Income $^{4}$ & Poverty & Income $^{4}$ \\
\hline Outgroup Hispanic husband ${ }^{2}$ & 1.163 & $1.157^{*}$ & $0.328 * * *$ & $2.665 * * *$ & $2.205^{*}$ & $0.589 * * *$ \\
\hline Outgroup Hispanic wife ${ }^{2}$ & 1.002 & $1.204 * *$ & $0.320 * * *$ & $2.783 * * *$ & $2.355^{*}$ & $0.737 *$ \\
\hline White husband & $0.653 * * *$ & $1.726^{* * *}$ & $0.139 * * *$ & $5.352 * * *$ & 1.129 & 1.193 \\
\hline White wife & $0.775 * * *$ & $1.430 * * *$ & $0.168 * * *$ & $4.401 * * *$ & 1.903 & 1.051 \\
\hline Black husband & 1.006 & 1.161 & $0.172 * * *$ & $3.259 * * *$ & & \\
\hline Black wife & 1.383 & 1.040 & $0.279 * * *$ & $3.744 * * *$ & & \\
\hline Other husband & $0.782 *$ & $1.525^{* * *}$ & $0.247 * * *$ & $3.675 * * *$ & & \\
\hline Other wife & 1.018 & $1.358 * * *$ & $0.281 * * *$ & $3.274 * * *$ & & \\
\hline \multicolumn{7}{|l|}{ Employment Status ${ }^{3}$} \\
\hline One spouse works & $2.361 * * *$ & $0.552 * * *$ & $2.115 * * *$ & $0.530 * * *$ & $2.090 * *$ & $0.583 * * *$ \\
\hline Neither spouse works & $2.896 * * *$ & $0.474 * * *$ & $2.160 * * *$ & $0.420 * * *$ & $5.459 * * *$ & $0.448 * *$ \\
\hline Husband's job & $0.983 * * *$ & $1.020 * * *$ & $0.972 * * *$ & $1.025 * * *$ & $0.973 * *$ & $1.020 * *$ \\
\hline Wife's job & $0.977 * * *$ & $1.020 * * *$ & $0.957 * * *$ & $1.023 * * *$ & $0.978 *$ & $1.022 *$ \\
\hline Husband's education & $0.885^{* * *}$ & $1.169 * * *$ & $0.841 * * *$ & $1.159 * * *$ & $0.884 * *$ & $1.163 * *$ \\
\hline Wife's education & $0.883 * * *$ & $1.167 * * *$ & $0.918 * * *$ & $1.108 * * *$ & $0.878 * *$ & $1.224 * *$ \\
\hline Husband's age & $0.986^{* * *}$ & $1.027 * * *$ & $0.987 * * *$ & $1.010^{* *}$ & 0.987 & $1.022 * *$ \\
\hline Wife's age & $0.966^{* * *}$ & $1.039 * * *$ & $0.966^{* * *}$ & $1.040 * * *$ & 0.985 & $1.016^{*}$ \\
\hline Model $\chi^{2}$ & 4812 & 18089 & 5789 & 6929 & 150 & 1150 \\
\hline$D F$ & 16 & 16 & 16 & 16 & 12 & 12 \\
\hline
\end{tabular}

Note:

1. Displayed marriage types are compared against endogamous marriages for each group.

2. See Note in Table 4 for definition of 'Outgroup Hispanic husband and wife'.

3. Employment status (one or neither spouse works) is compared against 'both spouses work'.

4. Income 5 times above Poverty. 
are not different from exogamous Cuban families that have non-Cuban Hispanic spouses.

Although most of the income differences are statistically significant in the model, one might wonder whether the dollar amount is sufficiently large to constitute a real-world difference. The coefficients seem to give a positive answer to this question. For example, per capita income in MexicanWhite husband families is $\$ 4,295$ higher than in endogamous Mexican families after the control variables are held constant. Since household size is 3.43 for the Mexican-White husband families, the total family income difference would be about $\$ 14,600$. This is a $29 \%$ difference of the average income for endogamous Mexican families $(\$ 50,008)$. Similar differences are respectively $18 \%, 12 \%$, and $7 \%$ between endogamous Mexican families and Mexican-White wife families, Mexican-Other non-Hispanic families, and Mexicanoutgroup Hispanic families.

The income difference is considerably larger for Puerto Ricans. After taking into account the control variables and household sizes, total family income for endogamous Puerto Ricans is $119 \%$ smaller than that for Puerto Rican-White husband families. Difference between endogamous Puerto Ricans and other exogamous Puerto Ricans is not quite as large, but still substantial. Income difference between endogamous Cubans and Cuban-White families, however, is relatively small at about $12.6 \%$ to $14.5 \%$.

Table 6 shows results of two logistic regressions with the same control variables as in Table 5. Column 1, 3, 5 and 2, 4, 6 are respectively logistic regression models on the likelihood of living in poverty and having an income 5 times above poverty for the three Hispanic groups.

Compared to endogamous Mexican families (Column 1), Mexican-White families and Mexican-other husband families are less likely to live in poverty, by about $22 \%$ to $35 \%$. Other exogamous Mexican families are not different from endogamous Mexican families in poverty rates. On the other hand, except Mexican-Black families, all exogamous Mexican families are more likely (by $16 \%$ to $73 \%$ ) to have an income 5 times above poverty than the endogamous Mexican families (Column 2).

For Puerto Ricans (Column 3 and 4), outmarriage is consistently associated with a lower chance to be poor and a higher chance to have an income 5 times above poverty, regardless to whom the outmarriage is formed. The odds ratios are especially large if the marriage is to a White: endogamous Puerto Rican families are 6 to 7 times more likely to live in poverty, but 4.4 to 5.4 times less likely to have the high income, than Puerto Rican-White families. Endogamous Cuban families (Column 5 and 6) are not different from Cuban-White families in poverty and income, but they are only half as likely to be poor and $26 \%$ to $41 \%$ more likely to have the high income than Cuban families with a non-Cuban Hispanic spouse.

In both Table $\mathbf{5}$ and $\mathbf{6}$, gender difference appears again as found in the previous tables, with outmarried Hispanic wife families having a slight advantage over outmarried Hispanic husband families. However, there is no gender difference when comparing endogamy with exogamy. If outmarried Hispanic men are financially better off than endogamous Hispanic men, the same would be true of Hispanic women.
In summary, findings from analysis of 2000 5\% PUMS national data gave adequate support to Hypothesis 1 and 2 . Hispanics who are married to Whites have higher individual SES and higher family financial resources than endogamous Hispanic individuals and families in all three nation-origin groups (Hypothesis 1). Similar differences are found between exogamous Hispanic and White families and exogamous Hispanic and non-White families (Hypothesis 2). Hypothesis 3 is rejected for Mexicans and Puerto Ricans, because their outmarriage is associated with higher SES regardless whom they outmarry. For Cubans, Hypothesis 3 is supported: Cubans outmarried to non-Whites have lower family SES than endogamous Cubans, who in turn have lower SES than Cubans outmarried to Whites. Cuban-Black and Cuban-Other marriages were not tested in regression analyses due to small sample sizes.

Mixed results are found for Hypothesis 4. The hypothesis is supported because there is no gender difference in the conclusions reached for Hypotheses 1, 2, and 3. Hispanics outmarried to Whites are financially better off than endogamous Hispanics and Hispanics outmarried to non-Whites, either the husband or the wife is exogamous. But the hypothesis is also rejected because Hispanic husband intermarriages have lower family financial resources than Hispanic wife intermarriages in all three Hispanic nationorigin groups, a clear gender difference in the financial outcome of intermarriage.

\section{CONCLUSION AND DISCUSSION}

The last few decades saw a rapid increase of Hispanic immigration, adding large numbers of immigrants to an already fast-growing Hispanic population in the United States. Hispanic assimilation into American society thus raised a lot of research interest. In this paper I studied Hispanic intermarriage and assimilation as theorized by classic and segmented assimilation theories, but focused on how intermarriage is related to family financial resources. The analysis is limited to U.S. born Hispanics in the 2000 census 5\% PUMS.

If assimilation into the mainstream society by way of intermarriage is as described by Gordeon's classic assimilation model, Hispanics who outmarried to Whites would have been culturally and structurally assimilated and have higher individual SES than endogamous Hispanics. If assimilation can also be described by segmented assimilation theory [16], Hispanics who outmarried non-Whites would have lower achieved status than Hispanics who outmarried Whites, and they would also have lower status than endogamous Hispanics who achieved structural assimilation but choose not to maritally assimilate. These two assimilation theories thus imply a hierarchy of family financial resources by types of marriage.

Four hypotheses were tested whether Hispanic family financial resources differ by types of marriage and by gender. These hypotheses assume that outmarriage to Whites is associated with higher family financial resources than are endogamy and outmarriage to non-Whites, and in turn endogamy is associated with higher average family income than outmarriage to non-Whites. Gender is considered to have no bearing on the financial outcome of intermarriage 
$[2,5]$. These hypotheses were also based in part on the equal status exchange perspective in intermarriage [34].

Classic assimilation theory received solid support from tests on Mexicans and Puerto Ricans, and for them outmarriage is related to higher family financial resources, especially when the marriage is to a White. The difference is both statistically significant and sufficiently large. Segmented assimilation assumptions were not supported for these two groups, because Mexicans and Puerto Ricans who are outmarried to outgroup Hispanics, Blacks and Others all have higher family financial resources than their endogamous counterparts. These findings indicate that Hispanic intermarriage with Blacks can also be a symbol of integration or assimilation into mainstream America, not into underclass America as predicted by the segmented assimilation theory. In part this may be explained by the continued retreat from marriage among African Americans, so that marriage in and by itself serves to filter out Blacks who may be associated with underclass America [35]. In other words, married Blacks, either endogamously or exogamously, are more likely to have followed the middle-class American values and are more structurally assimilated than those who do not marry [36].

Segmented assimilation assumptions received some support from tests on Cubans. Cubans who are outmarried to Whites have higher family financial resources than Cubans who are endogamously married, but the latter are better off than Cubans who are outmarried to non-Whites. However, intermarriages between Cubans and non-Whites may not necessarily be symbols of assimilation into 'underclass' America [2], since families formed by these marriages are only comparatively low in financial resources, not absolutely. Hispanic intermarriage therefore does not produce convincing evidence to support segmented assimilation theory via intermarriage.

Gender is found independent of probabilities of intermarriage for Hispanics, but interacts with the socioeconomic status of their intermarried families. To be specific, Hispanic men and women have roughly the same probability of being intermarried, but intermarried families where the wife is Hispanic are financially better off than intermarried families where the husband is Hispanic, after race of the nonHispanic spouse is controlled. For example, in WhiteHispanic families, SES is higher if the wife is Hispanic than if the husband is Hispanic. This difference remains true regardless of the race of the non-Hispanic spouse.

Our data do not offer a direct explanation why there is such a SES difference by gender for intermarried Hispanic families. It has been noted in the literature that the effect of gender on intermarriage differs widely across racial and ethnic groups in the U.S. For example, Asian women are more likely to outmarry than Asian men while Black women are less likely to outmarry than Black men, but this gender difference in the probability of outmarriage is not observed between Hispanic men and Hispanic women. On the other hand, intermarried Asian families do not differ in SES by gender as Hispanics do [11,37]. Apparently further work is needed to fully explain the dynamics of the gender difference between and within groups.
In conclusion, this study provided adequate support to the assumption that intermarriage is associated with family financial well-being. The most important finding is that outmarriage to Whites is consistently related to higher SES for all Hispanics, giving support to the argument that the classic assimilation theory can be applied to the late 20th century immigrants and their U.S. born generations [20]. Exogamous Hispanics have relatively higher individual SES than their endogamous counterparts, and they tend to marry a spouse with comparable SES, leading to higher family financial resources than those of endogamous Hispanics. Children in these families have a more favorable socioeconomic environment that would in turn help their structural assimilation. Their mixed racial and ethnic heritage and higher family SES could also prompt them to higher probabilities of intermarriage, thus speeding up the assimilation process as Gordon hypothesized. On the other hand, the majority of low-SES Hispanics (over two thirds of U.S. born Mexicans and Puerto Ricans) are endogamously married, and have substantially lower family SES than those who are outmarried to Whites. Endogamy and low SES are often related to life in an enclosed social circle solidified by ethnic languages, low human capital and lack of middle class jobs [16]. Those circumstances could adversely affect the children in these families and delay their assimilation, making them less likely to outmarry. Intermarriage, which is often taken as a symbol of successful assimilation, thus may also serve as a social class filter to keep low-SES individuals in endogamy. Because all children in endogamous Hispanic marriages inherit a Hispanic background but not all children in exogamous Hispanic marriages do so [2], social class and Hispanic heritage may tend to be negatively correlated through generations via intermarriage.

Cuban intermarriages, on the other hand, suggest that intermarriage may only be weakly associated with family SES after a minority group has achieved sufficient structural assimilation. What is sufficient is debatable, but it is reasonable to use the national average as a benchmark. Cubans are the only group out of the three that have higher average individual SES than the national average (Table 3), and the association between their intermarriage and family SES also deviates from the patterns observed for Mexicans and Puerto Ricans. Similar results have been reported from studies on Asian intermarriages (East Indians and Japanese, for example), whose highest achievers tend to either intermarry Whites or marry endogamously, so that both types have very high family SES. Asian intermarriages with nonWhites, on the other hand, are often associated with lower family SES than is Asian endogamy [37].

When Hispanic intermarriage and its effect on inter-generational family SES are examined in comparison to other racial and ethic groups, it is clear that the patterns that were observed in this study are not exclusive to Hispanics. Minorities with a relatively low group status tend to experience what Hispanics did in terms of status exchange in intermarriage. The effect of intermarriage on family SES across generations is even greater for smaller minorities (such as Hawaiians and Native Americans) than for Hispanics [10]. In other words, although this study focused on the U.S.-born Hispanic Americans, its results can be reasonably generalized to other groups, as evidenced by similar studies. Intermarriage's impact on family SES for 
Whites, however, is largely negligible since only a very small proportion of Whites outmarry [3,37]. Although this study is based intermarriage between different racial and ethnic groups in the U.S., the patterns revealed in the data can also be reasonably generalized to all settings in which intermarriage between groups occur, as long as there is a group status difference in the society.

The 2000 census 5\% PUMS imposed several limitations in this study. First, the data only allowed tests on existing marriages, which may be affected by differential marital dissolutions. Namely, low-SES couples and intermarried couples tend to have higher probabilities of marital dissolution [31], and may thus be less represented in the PUMS than other marriages. Second, length of marriage and immigrant generations are not available in the data, making it impossible to compare status change after marriage or to examine whether across generations Hispanics were filtered by SES in outmarriage. Further studies on immigrant assimilation, intermarriage and family financial status would benefit from testing longitudinal data where these control variables are available. Lastly, this study only examined married couple households, which are in general financially better off than other types of households. With married couple households fast retreating from being the most common type of households, immigrant minority assimilation may present a variety of formats that cannot be studied via marriage patterns.

\section{REFERENCES}

[1] Passel J. Unauthorized migrants: numbers and characteristics. Background briefing prepared for Task Force on Immigration and America's Future. Washington, DC: Pew Hispanic Center 2005.

[2] (a) Lee SM, Edmonston B. New marriages, new families: U.S racial and Hispanic intermarriage. Popul Bull 2005; 60 (2); (b) Rosenfeld MJ. Measures of assimilation in the marriage market: Mexican Americans 1970 - 1990. J Mar Fam 2002; 64: 152-62; (c) Saenz R. Latinos and the changing face of America. Washington, DC: Russell Sage Foundation and Population Reference Bureau 2004.

[3] U.S. Bureau of the Census. Statistical abstract of the United States, $2004-2005124^{\text {th }}$ ed. Washington, DC: U.S. Government Printing Office 2005 .

[4] U.S. Bureau of the Census. Projections of the resident population by race, Hispanic origin, and nativity 2000. [Retrieved June 10, 2008]. Available from http://www.census.gov/population/ www /projections/natsum.html

[5] (a) Gordon M. Assimilation in American life. New York: Oxford University Press 1964; (b) Portes A, Rumbaut R. Legacies: the story of the immigrant second generation. Berkeley: University of California Press 2001

[6] Rosenfeld MJ, Kim BS. The independence of young adults and the rise of interracial and same-sex unions. Am Soc Rev 2005; 70: 54162.

[7] Smith J, Edmonston B, Eds. The New Americans: economic, demographic, and fiscal effects of immigration. Washington, DC: National Academy Press 1997.

[8] (a) U.S. Bureau of the Census. Census of population: general social and economic characteristics. Final report PC (1)-13. Washington, DC: Government Printing Office 1970; (b) U.S. Bureau of the Census. Census of population and housing. Washington, DC: Government Printing Office 1980; (c) U.S. Bureau of the Census. Statistical abstract of the United States. Washington, DC: Government Printing Office 1990; (d) U.S. Bureau of the Census. Census SF1, Table DP-1 profiles of general demographic characteristics. Washington, DC: U.S. Government Printing Office 2000.

[9] Fu X. Impact of socioeconomic status on inter-racial mate selection and divorce. Soc Sci J 2000; 43(3): 239-58.
[10] $\mathrm{Fu} \mathrm{X}$, Heaton TB. Inter-racial marriage, family type and consequential family socioeconomic well-being in Hawaii. In: Proceedings of Multiethnic Families Conference 2006, University of Hawaii. Honolulu, HI.

[11] (a) Anderson RN, Saenz R. Structural determinants of Mexican American intermarriage, 1975-1980. Soc Sci Q 1994; 75(2): 41430; (b) Gilbertson G, Fitzpatrick J, Yang L. Hispanic intermarriage in New York City: New evidence from 1991. Int Mig Rev 1996; 30(2): 445-59; (c) Qian Z. Breaking racial barriers: variation in interracial marriage between 1980 and 1990. Demography 1997; 34: $263-76$

[12] (a) Hansen ML. The problem of the third generation immigrant (Rock Island, IL: Augustana Historical Society 1938). Reprinted as The third generation in America. Commentary 1952; 14: 492-500; (b) Merton RK. Intermarriage and the social structure: fact and theory. Psychiatry 1941; 4: 361-74.

[13] Bean FD, Lee J, Batalova J, Leach M. The American people: immigration and fading color lines in America. New York, NY: Russell Sage Foundation 2004.

[14] Healey JF. Race, ethnicity, gender and class. Thousand Oaks, CA: Pine Forge Press 2009

[15] Kritz M, Gurak DT. The American people: Census 2000immigration and a changing America. New York, NY: Russell Sage Foundation; and Washington DC, Population Reference Bureau 2004

[16] Portes A, Zhou M. The new second generation: segmented assimilation and its variants. Ann Am Acad Pol Soc Sci 1993; 530: 74-96.

[17] (a) Massey D. The new immigration and ethnicity in the United States. Popul Dev Rev 1995; 21: 631-52; (b) Valentine S, Mosley G. Acculturation and sex-role attitude among Mexican Americans: a longitudinal analysis. Hisp J Behav Sci 2000; 22: 104-204.

[18] (a) Portes A, Rumbaut R. Immigrant America: a portrait. $2^{\text {nd }}$ ed. Berkeley: University of California Press 1996; (b) Walters M. Optional ethnicities: for Whites only? In Pedraza S, Rumbaut R, Eds. Origins and destinies; immigration, race, and ethnicity in America. Belmont, CA: Wadsworth 1996.

[19] Bean FD, Stevens G. America's newcomers and the dynamics of diversity. New York: Russell Sage 2003.

[20] Alba R, Nee V. Remaking the American mainstream: assimilation and contemporary immigration. Cambridge, MA: Harvard University Press 2003

[21] (a) Fu X, Heaton TB. Status exchange in intermarriage among Hawaiians, Japanese, Filipinos and Caucasian in Hawaii: 19831994. J Comp Fam Stud 2000; 31(1): 45-61; (b) Choen R, Cheng YA. Partner choice and the differential retreat from marriage. J Mar Fam 2006; 68: 1-10; (c) Schwartz CR, Mare RD. Trends in educational assortative marriages from 1940 to 2003. Demography 2005; 42 (4): 621-46.

[22] (a) Davis K. Intermarriage in caste societies. Am Anthrop 1941; 43: 376-95. Grossbard-Shechtman SA, Neideffer M. Women's hours of work and marriage market imbalances. In: Persson I, Jonung C, Eds. Economics of the family and family policies. London: Routledge 1997; (b) Kalmijn M. Trends in Black/White intermarriage. Soc Forum 1993; 72: 119-46.

[23] Rosenfeld MJ. A critique of exchange theory in mate selection. Am J Soc 2005; 110 (5): 1284-325.

[24] Fernandez R, Guner N, Knowles J. Love and money: a theoretical and empirical analysis of household sorting and inequality. Q J Econ 2005; 120(1): 273-344.

[25] Mare RD. Five decades of educational assortative mating. Am Soc Rev 1991; 56: 15-32.

[26] Hwang S, Saenz R. The problem posed by immigrants married abroad on intermarriage research: the case of Asian Americans. Int Mig Rev 1990; 24 (3): 563-76.

[27] Fix M, Passel J, Sucher K. Trends in naturalization. Washington DC: Urban Institute 2003.

[28] Lee SM, Fernandez M. Trends in Asian American racial/ethnic intermarriage: a comparison of 1980 and 1990 census data. Soc Perspect 1998; 41(2): 323-42.

[29] Alba R, Golden RM. Patterns of ethnic marriage in the United States. Soc Forum 1986; 65: 202-23.

[30] (a) Heaton TB, Albrecht ST. The Changing pattern of interracial marriage. Soc Biol 1996; 43(3-4): 203-17; (b) Jacobs JA, Labov TG. Gender differentials in intermarriage among sixteen race and ethnic groups. Soc Forum 2002; 17(4): 621-46. 
[31] (a) Fu X. Impact of socioeconomic status on inter-racial mate selection and divorce. Soc Sci J 2006; 43(3): 239-58; (b) Raymo $\mathrm{JM}$, Xie Y. Temporal and regional variation in the strength of educational Homogamy. Am Soc Rev 2000; 65: 773-81.

[32] (a) Ganzeboom HBG, Treiman DJ. Internationally comparable measures of occupational status for the 1988 international standard classification of occupations. Soc Sci Res1996; 25: 201-39; (b) Treiman DJ. Occupational prestige in comparative perspective. New York: Academic Press 1977.

[33] (a) Ganzeboom HBG, De Graaf PM, Treiman DJ. A standard international socio-economic index of occupational status. Soc Sci Res 1992; 21: 1-56; (b) Gilbert D, Kahl JA. The American class structure. $5^{\text {th }}$ ed. Belmont, CA: Wadsworth 1998.
[34] Fu X. Interracial marriage and family socio-economic well-being: equal status exchange or caste status exchange? Soc Sci J 2008; 45(1): 132-55.

[35] (a) Cherlin AJ. Marriage, divorce, remarriage. Revised and enlarged ed. Cambridge, MA: Harvard University Press 1992; (b) Schoen R, Kluegel JR. The widening gap in Black and White marriage rates: the impact of population composition and differential marriage propensities. Am Soc Rev 1998; 53: 895 907.

[36] (a) Tucker MB, Mitchell-Kernan C. New trends in Black American interracial marriage: the social structural context. J Mar Fam 1990; 52: 209-18; (b) Schoen R, Cheng YA. Partner choice and the differential retreat from marriage. J Mar Fam 2006; 68: 1-10.

[37] Fu X, Hatfield M. Intermarriage and segmented assimilation: U.S. born Asians in 2000, J Asian Am Stud 2008; 11(3): 249-77.

\section{(C) Xuanning Fu; Licensee Bentham Open.}

This is an open access article licensed under the terms of the Creative Commons Attribution Non-Commercial License (http://creativecommons.org/licenses/by$\mathrm{nc} / 3.0 /$ ), which permits unrestricted, non-commercial use, distribution and reproduction in any medium, provided the work is properly cited. 